\title{
The Application and Exploration of Sponge's City Idea in Urban Plan- ning
}

\author{
Yunnan Provincial Transportation Planning and Design Institute, Kunming, Yunnan 6500000
}

\section{Introduction}

\section{Sponge city connotation}

1.1 Sponge city in the construction and development process, the first need to focus on the surrounding natural environment is to minimize the impact, from another point of view, in the construction of urban planning at the same time, as the relevant construction units to the local hydrogeological and ecological environment for a comprehensive, to rely on. Without affecting the local natural environment at the same time construction and development, sponge city. Through the comprehensive consideration of all aspects of factors to improve the procedures for the surface runoff rainwater discharge storage and comprehensive utilization of the ability to build and build a good water circulation system.

1.2 In general sponge city construction and development need to pay attention to the following aspects of the problem. First of all, we should pay attention to the protection of the ecological environment, followed by ecological protection on the basis of the original ecological system to repair. Finally, the local natural environment and the ecological environment to protect, in the process of urban construction and planning, we must adhere to the concept of sustainable development, so as to maximize the protection of the city's ecological and environmental optimization. Reduce the development of sensitive areas and fragile areas, reduce the impact on the urban hydrological environment, in the original urban construction on the basis of the city's water resources protection and recycling. To develop the system design.

\subsection{Sponge city construction} which has three major drainage. There are different requirements for the functional partition of the drainage system, and the present situation is not affected by the ecosystem environment. The establishment of rainwater storage and development system. Thus forming a complete urban, irrigation and rainwater use optimization, thereby enhancing the city's flood discharge capacity, in the normal, irrigation and domestic water under the circumstances, for the rainstorm flood control and the occurrence of waterlogging has a positive effect.

\section{Some Suggestions on Sponge City Construction}

2.1 Active use of pilot construction strategy

Sponge city construction theory put forward, after years of practice has proved that in the future urban construction among the application of sponge city, with a larger space, because the sponge city construction for the city's basic development and future development direction, there is. But in the process of construction and development of sponge city, it is necessary to take a pilot project in the process of sponge city planning and development. In the process of construction and development of sponge city, it is necessary to take the pilot project in the process of sponge city planning and development. Construction strategy, which in

\begin{abstract}
With the rapid development of social economy, the shortage of natural resources is becoming more and more prominent. China is a large country with a large population and a large resource base. However, the consumption rate of resources is very fast. In order to solve the problem of urban water supply the problem of China in the development of urban construction which put forward the theory of sponge city construction. As proof of practice, Sponge city construction and development, for the protection of the natural environment and water conservation has a more important significance. Based on this, this paper discusses the use of sponge city concept in urban planning and hopes to make a practical reference for future concrete work.
\end{abstract}

Key words: sponge city; urban planning

Published online: 15th July, 2017

the development of sponge city. It is of great significance. First of all, it can accumulate experience and avoid unnecessary economic losses. It can also provide samples and reference for future sponge city construction. In order to make the construction and development of sponge 
city in China, it has stronger scientific basis. The first need to select the water problem is more serious urban areas as a pilot project, but China's current urban construction and development process which there are more problems, and urban construction is more complex, the choice of the need to ensure that the choice of large and medium-sized cities on the choice of a reasonable proportion, as a reference basis, due to China's current urban development, there is a big difference, so in the process of urban construction must be the actual situation, as a reference basis, according to the actual development of the local design and development, so the pilot reasonable choice for the development and construction of sponge city has a more important impact, so the pilot area is reasonably distributed in large and medium-sized cities on a more scientific, as the city construction of the relevant workers and researchers in the sponge city construction process The Need to learn from foreign advanced experience, and constantly strengthen their overall quality, for the development and development of China's sponge city to make their due contribution to the construction and development of sponge city is a long way to go, we need to work together.

2.2 Urban planning first requires a master plan

In the sponge city planning and design at the same time, we must first of the local natural environment and the ecological environment and urban development of the specific situation, do an assessment, according to the assessment of the content of scientific and reasonable risk, resulting in a specific planning program. According the planning program, to carry out research and discussion to develop a reasonable construction plan, in the discussion of the results and the process of urban infrastructure. The need for the city's water resources carrying capacity to continue to investigate, and then come to the assessment results. And finally determine the city's development direction and development goals. In the process of planning and construction of sponge city, the need for the city's road water system, such as special planning and design, in the planning when the sponge city construction concept really applied in order to fundamentally solve the city's waterlogging and water pollution problems, and thus protect the city water is safe.

\subsection{Controlled Detailed Planning}

Sponge city in the planning and design, according to the local topography and geomorphology and address, the characteristics of a detailed division of the local hydrological conditions and basic data through a comprehensive analysis of the public risk assessment, the main purpose is to reduce the impact of local nature Environment in the local, public facilities and supporting municipal not involved in the construction of sponge on the basis of the proposed scientific and rational construction goals. For the city's green rate, building density and floor area ratio of a comprehensive layout, so as to clear the catchment area, for the rain control efforts.

\subsection{Protect and repair natural sponge}

In urban planning, we should also note that the natural restoration of the human body, such as the surrounding urban wetlands, lakes, forests and grasslands, is an important natural sponge that can play a role in regulating water flow and water purification, which has an important value. And natural sponge protection and repair mainly in the following ways: designated construction area and non-construction area, through the mandatory means to protect the natural sponge, to prevent damage; can restore the natural ecology, such as water, dredging mud plant cultivation and ecological construction measures, The impact of the green ecosystem so natural sponge can play a very good ability to flood and repair natural ecology; can establish ecological corridors to protect natural sponge. Through the construction of eco-corridors conducive to the development of sponge city, can form a system of ecological sponge, can better play the role of natural sponge.

\section{Conclusion}

In general, the construction of sponge city is of great significance to economic development and environmental protection, at the same time pay attention to repair, natural sponge to speed up the process of artificial transformation of the ecological environment, improve the city's rainwater and water resources protection. But the ability of sponge city development, the protection of water resources in China has an important impact on the future work process, the relevant staff to strengthen this area of technical management and optimization measures.

\section{References:}

[1] Meng Ling Chao. Based on the "Sponge City" Concept Of Urban Ecological Landscape Remodeling [D]. Henan University, 2015.

[2] ZHAO Peng, ZHENG Lan-xiang. Study on Urban Planning Method Based on Sponge City Concept [J]. Construction Science and Technology, 2016, 02: 64-65.

[3] Deng Guoan. Based on the Sponge City Concept Of Urban Planning Method [J]. Building materials and decoration, 2016, 26: 147-148.

[4] Yi Kim Hom. Application and Suggestion of Sponge City Concept in Urban Planning [J]. Science and Technology Innovation Guide, 2016, 18: 102-103. 